\title{
Article \\ Microclimatic effects on the preservation of finds in the Visitor Centre of the Archaelological site 1a Imperial Palace Sirmium
}

\author{
Aleksandra Ugrinović' ${ }^{,}$Budimir Sudimac', ${ }^{*}$ and Željko Savković ${ }^{2}$ \\ 1 Department of Architectural Technology, the University of Belgrade's Faculty of Architecture, 73/2 Kralja \\ Aleksandra Blvd, Belgrade, Serbia; aleksandra.ugrinovic@arh.bg.ac.rs \\ 2 Institute of Botany and Botanical Garden "Jevremovac", University of Belgrade, Faculty of Biology, Ta- \\ kovska 43, 11 000, Belgrade, Serbia; zsavkovic@bio.bg.ac.rs \\ * Correspondence: sudimac@arh.bg.ac.rs
}

\begin{abstract}
When an archaeological site is roofed over for better display of the finds and more comfortable experience of the audience, the intervention undoubtedly changes the microclimatic conditions in the site. Although sudden changes in microclimatic factors are known to damage and/or destroy archaeological finds, in Serbia, their impact and its analysis are neglected. There is no continuous monitoring and control of microclimatic conditions or their impact on architectural remains in archaeological sites. This paper aims at stressing the necessity of introducing mandatory microclimatic monitoring in the process of designing protective structures over archaeological sites. For the purpose of this paper, the actual air temperature and air humidity values were monitored in the Visitor Centre of the Archaeological site 1a Imperial Palace Sirmium, designated cultural heritage of exceptional importance. The contamination level of archaeological finds in the site was microbiologically analysed. The findings showed that during the phase of microclimatic monitoring (February-April 2021), air humidity was almost constantly above the levels set by standards and recommendations for museum collections $(>60 \%)$. The highest levels of air humidity, amounting to $93 \%$, were recorded in February, with daily oscillations of up to $30 \%$; the lowest recorded temperature was $0.3^{\circ} \mathrm{C}$, with the maximum daily oscillations of $6^{\circ} \mathrm{C}$. Microbiological analysis revealed great diversity in the deterioration level of the finds, which can be attributed to the time lapse between the last conservation and the present. The comparative analysis of microclimatic monitoring and microbiological analysis results identified high levels of relative air humidity as the dominant factor in the increased microbiological contamination of the finds. The findings also pointed to the necessity of continuous microclimatic monitoring during the actual usage of the facility in order to provide the sustainable display and preservation of the finds on the premises.
\end{abstract}

Keywords: protective structures; microclimatic monitoring; microbiological deterioration of architectural finds; Archaeological site 1a Imperial Palace Sirmium

\section{Introduction}

Modern solutions for protecting, preserving and displaying archaeological finds belonging to architectural heritage in situ are not uncommon in global practice. Since 2000 and the European Landscape Convention, ratified by Serbia in 2011, display of the finds in situ is recognised as a potential for promoting creative industries and cultural tourism. Along the same line, cultural heritage is recognised as an important factor in city branding and the strategies of cities for economic growth and development. In situ presentation of the finds pose a challenge before numerous professionals involved in the interdisciplinary and comprehensive process, from those involved in archaeological research to those specialised in displaying the finds and opening sites for the public.

The first instances of sheltering archaeological sites in early $19^{\text {th }}$ century aside, most protective structures that served both the purpose of preserving the finds and their display to the public in situ were erected in 1960s. However, the development of protective 
structures and visitor centres in archaeological sites has been particularly intensified in the last decade of $20^{\text {th }}$ century and early $21^{\text {st }}$ century, with the new concept of musealisation, based on the tendency to display the finds to the visitors in situ. Depending on the characteristics of local climate and the types of finds to be displayed, one can opt for open protective structures (canopies and overhangs), semi-open ones (shelters) or those fully closed and with a controlled access, in the shape of a building with permanent museological display of the finds throughout the year. Experience in European and domestic protective practice differ as regards the application of protective structures in archaeological sites [1]. In some sites, the erection of these structures has raised new issues, directly or indirectly affecting the preservation of the finds [2-6]. One of the issues has most certainly been a sharp change of microclimatic conditions and the establishment of new microclimatic regime. Such climatic shock can cause the materials of the finds to deform and damage the finds [7]. Also, frequent oscillations of temperature and relative air humidity result in chemical, mechanical and biological deterioration of the finds. Having all that in mind, inside protective structures and permanent facilities built in archaeological sites functioning as museums in situ, securing proper microclimatic conditions for both preserving and displaying artifacts and providing comfort for the visitors is of utmost importance. Microclimatic conditions can only be controlled indoors, i.e. in closed protective structures. As opposed to the extensive number of papers discussing optimum microclimatic conditions for museum collections on display [8-12] or those in historic buildings repurposed as museums [13-17], depots [18], and archives and libraries [19], scientific research on monitoring microclimatic regimes inside protective structures and visitor centres on archaeological sites, presented and published in a paper, are quite rare [20-22]. What makes archaeological sites specific is primarily the impact of the environmental conditions (ground waters, for example). In addition to microclimatic conditions in the site, preservation of architectural remains is also determined by the characteristics of the building materials, which are usually porous, hygroscopic, inorganic, and especially sensitive to the oscillations of the relative air humidity, since it disturbs the fine balance of humidity in them [23]. To adapt to the constant change of the surrounding conditions, these materials need to absorb and lose moisture. The change in the usual content of moisture results in dimensional change that cause physical damage, breakage, and deformation. Large temperature oscillations are the cause of chemical deterioration, while high levels of relative air humidity bring about the biological deterioration of the finds [11].

Since the environmental conditions are singular, i.e. differ from site to site, the values of microclimatic parameters of air temperature and relative air humidity are specifically monitored in the Visitor Centre of the Archaeological site 1a Imperial Palace Sirmium. Microclimatic monitoring and microbiological research there were triggered by the discovery of microorganisms and biological agents on the finds. Due to the large scope of finds in the site, this paper focuses solely on the research of microclimatic parameters, air temperature and relative air humidity, on the preservation of the biologically contaminated ancient mosaics.

The purpose of the work is to determine the values of these two microclimatic parameters and their daily oscillations in the Visitor Centre of the Archaeological site 1a Imperial Palace Sirmium, and to detect the level of biological contamination of the finds. By means of comparative analysis of microclimatic monitoring and microbiological study results, this research is to determine whether the conditions in situ pose a hazard to the preservation of the displayed finds.

\section{Recommended and standard microclimatic conditions in museums}

Recommendations and standards of optimum microclimatic conditions has changed from the approach founded on ideal, constant microclimatic environmental conditions that guarantee the preservation of the artefacts/finds, to that favouring conditions ac- 
ceptable both from the perspective of preservation of the finds and from the point of view of visitor and their comfort during the visit.

With the development of heating, ventilation, and conditioning systems, the last century saw the growing number of research on the impact of microclimatic conditions of the environment on the preservation of museum artefacts, serving as a basis for developing conditions optimisation models. The first approach - the statistical model of optimising the artefacts preservation and display conditions in the museum - promotes the establishment of constant, permanent microclimate throughout the year with the view to reducing the risk of their deterioration [24]. Therefore, the optimum microclimatic parameters should be determined for each artefact and its building material to preserve it. Consequently, museum collections are sorted by the type of material the artifacts are made of. For heterogenous, composite materials the mean value of microclimatic parameters was used. Based on the research carried out by Garry Thompson, an authority on the subject, the optimum temperatures for displaying most artefacts are $19^{\circ} \mathrm{C}$ in winter and $24^{\circ} \mathrm{C}$ in summer, coupled with the recommended year-round relative air humidity ranging between $50 \%$ and $55 \%$, with the maximum allowed oscillation of 5\% [24]. Although the constant microclimate proposed by this model secure the preservation of the finds, such model is uneconomical as regards the energy consumption for heating, air-conditioning and dehumidification, coupled with the high maintenance costs. To reach the sustainable solution, it is necessary to make compromise between the optimum values that secure the preservation of artefacts (based on the characteristics of their building materials) and the energy consumption for heating, air-conditioning, and providing comfort for visitors. The question is how to provide the optimum conditions for the display of finds without large investment in thermal and technical systems, so that the solution be financially acceptable, energy-efficient, and environmentally friendly. This question is still pending for an answer, lying at the core of the dynamic model of microclimate optimisation.

The statistical model is nowadays abandoned, although some museums still keep their collections in constant, stable microclimate [19]. Large energy consumption and $\mathrm{CO}_{2}$ emission were the reason for adoption of the dynamic model, where variations of climatic parameters are allowed. However, the variation curve must not be extreme but should be kept within the recommended ranges of allowed daily oscillations of microclimatic parameters. The dynamic model is based on the concept of energy sustainability and environment protection and promotes the reduction of $\mathrm{CO}_{2}$ emission and the use of renewable energy sources. The optimisation of parameters in this model is achieved passively, by applying the concept of "passive conditioning" [11]. The concept involves good thermal insulation, a hermetic cover and high thermal and hygric inertia of a structure.

The dynamic model has yielded several standards and recommendations for modeling microclimatic conditions. All of them are characterised by a small difference in the recommended ranges of parameters and the allowed oscillation of the temperature and relative humidity values on a daily and seasonal basis, but substantially they are all based on the same principle - the dynamic model. Among them are British and Italian standards, standards of the European Committee for Standardization (CEN), recommendations of organisations dealing with the preservation and conservation of artefacts and finds, and those suggested by different associations and organisations. Since this is a multidisciplinary area and calls for cooperation of experts from different fields of expertise, in prescribing standards, guidelines and recommendations each organisation puts into focus its own area of expertise.

The American Society of Heating, Refrigerating and Air-Conditioning Engineers (ASHRAE) has issued a set of regulations for museums, archives, and libraries, depending on the type of collection and the category of a facility [25]. The document defines five classes of microclimatic modes based on the acceptable ranges of temperature and relative air humidity during short-term oscillations and seasonal adjustments, taking into account the risks for the finds. The most controlled conditions are in Class AA, while 
Class D has the most relaxed conditions, where only the air humidity is controlled (see Figure 1).

\begin{tabular}{|c|c|c|c|c|}
\hline \multirow[b]{2}{*}{$\begin{array}{c}\text { Set Point or } \\
\text { Annual Average }\end{array}$} & \multicolumn{3}{|c|}{$\begin{array}{c}\text { Maximum Fluctuations and } \\
\text { Gradients in Controlled Spaces }\end{array}$} & \multirow[b]{2}{*}{ Collection Risks and Benefits } \\
\hline & Class of Control & \begin{tabular}{|c|}
$\begin{array}{c}\text { Short Fluctuations } \\
\text { plus }\end{array}$ \\
Space Gradients
\end{tabular} & $\begin{array}{c}\text { Seasonal } \\
\text { Adjustments in } \\
\text { System Set Point }\end{array}$ & \\
\hline $\begin{array}{l}50 \% \text { rh } \\
\text { (or historic annual } \\
\text { average for } \\
\text { permanent } \\
\text { collections) }\end{array}$ & $\begin{array}{l}\text { AA } \\
\text { Precision control, } \\
\text { no seasonal } \\
\text { changes, with } \\
\text { system failure } \\
\text { fallback }\end{array}$ & $\pm 5 \% \mathrm{rh}, \pm 2 \mathrm{~K}$ & $\begin{array}{l}\text { Relative humidity } \\
\text { no change } \\
\text { Up } 5 \mathrm{~K} \text {; down } 5 \mathrm{~K}\end{array}$ & $\begin{array}{l}\text { No risk of mechanical damage to most artifacts and } \\
\text { paintings. Some metals and minerals may degrade } \\
\text { if } 50 \% \text { rh exceeds a critical relative humidity. } \\
\text { Chemically unstable objects unusable within } \\
\text { decades. }\end{array}$ \\
\hline \multirow{5}{*}{$\begin{array}{l}\text { Temperature set } \\
\text { between } 15 \text { and } \\
25^{\circ} \mathrm{C} \\
\text { Note: Rooms } \\
\text { intended for loan } \\
\text { exhibitions must } \\
\text { handle set point } \\
\text { specified in loan } \\
\text { agreement, } \\
\text { typically } 50 \% \text { rh, } \\
21^{\circ} \mathrm{C} \text {, but } \\
\text { sometimes } 55 \% \text { or } \\
60 \% \text { rh. }\end{array}$} & $\begin{array}{l}\text { A } \\
\text { Precision control, } \\
\text { some gradients or } \\
\text { seasonal changes, }\end{array}$ & $\pm 5 \% \mathrm{rh}, \pm 2 \mathrm{~K}$ & $\begin{array}{l}\text { Up } 10 \% \mathrm{rh} \text {, } \\
\text { down } 10 \% \mathrm{rh} \\
\text { Up } 5 \mathrm{~K} ; \\
\text { down } 10 \mathrm{~K}\end{array}$ & \multirow[t]{2}{*}{$\begin{array}{l}\text { Small risk of mechanical damage to high- } \\
\text { vulnerability artifacts; no mechanical risk to most } \\
\text { artifacts, paintings, photographs, and books. } \\
\text { Chemically unstable objects unusable within } \\
\text { decades. }\end{array}$} \\
\hline & $\begin{array}{l}\text { system failure } \\
\text { fallback }\end{array}$ & $\pm 10 \%$ rh, $\pm 2 \mathrm{~K}$ & $\begin{array}{l}\text { RH no change } \\
\text { Up } 5 \mathrm{~K} \text {; down } 10 \mathrm{~K}\end{array}$ & \\
\hline & $\begin{array}{l}\text { B } \\
\text { Precision control, } \\
\text { some gradients } \\
\text { plus winter } \\
\text { temperature } \\
\text { setback }\end{array}$ & $\pm 10 \% \mathrm{rh}, \pm 5 \mathrm{~K}$ & $\begin{array}{l}\text { Up } 10 \% \text {, } \\
\text { down } 10 \% \text { rh } \\
\text { Up } 10 \mathrm{~K} \text {, but not } \\
\text { above } 30^{\circ} \mathrm{C}\end{array}$ & $\begin{array}{l}\text { Moderate risk of mechanical damage to high- } \\
\text { vulnerability artifacts; tiny risk to most paintings, } \\
\text { most photographs, some artifacts, some books; no } \\
\text { risk to many artifacts and most books. } \\
\text { Chemically unstable objects unusable within } \\
\text { decades, less if routinely at } 30^{\circ} \mathrm{C} \text {, but cold winter } \\
\text { periods double life. }\end{array}$ \\
\hline & $\begin{array}{l}\text { C } \\
\text { Prevent all high- } \\
\text { risk extremes }\end{array}$ & \multicolumn{2}{|c|}{$\begin{array}{l}\text { Within } 25 \text { to } 75 \% \text { rh year-round } \\
\text { Temperature rarely over } 30^{\circ} \mathrm{C} \text {, } \\
\text { usually below } 25^{\circ} \mathrm{C}\end{array}$} & $\begin{array}{l}\text { High risk of mechanical damage to high- } \\
\text { vulnerability artifacts; moderate risk to most } \\
\text { paintings, most photographs, some artifacts, some } \\
\text { books; tiny risk to many artifacts and most books. } \\
\text { Chemically unstable objects unusable within } \\
\text { decades, less if routinely at } 30^{\circ} \mathrm{C} \text {, but cold winter } \\
\text { periods double life. }\end{array}$ \\
\hline & $\begin{array}{l}\text { D } \\
\text { Prevent } \\
\text { dampness }\end{array}$ & \multicolumn{2}{|c|}{ Reliably below $75 \%$ rh } & $\begin{array}{l}\text { High risk of sudden or cumulative mechanical } \\
\text { damage to most artifacts and paintings because of } \\
\text { low-humidity fracture; but avoids high-humidity } \\
\text { delamination and deformations, especially in } \\
\text { veneers, paintings, paper, and photographs. } \\
\text { Mold growth and rapid corrosion avoided. } \\
\text { Chemically unstable objects unusable within } \\
\text { decades, less if routinely at } 30^{\circ} \mathrm{C} \text {, but cold winter } \\
\text { periods double life. }\end{array}$ \\
\hline
\end{tabular}

Figure 1. Proposed air temperature and relative air humidity values in museums according to ASHRAE. Source: [25].

For the purpose of this paper, air temperature and relative air humidity values taken in the Visitor Centre of Archaeological site 1a Imperial Palace Sirmium are analysed against the recommendations and guidelines of the declaration on the proposed values of microclimatic conditions securing the preservation of artefacts issued by the Australian Institute for the Conservation of Cultural Material (AICCM) and the document on the preservation of hygroscopic material issued by the European Biyot Group in 2014 [26]. AICCM recommends $15-25^{\circ} \mathrm{C}$ temperature range, with the acceptable daily fluctuations of $+/-4^{\circ} \mathrm{C}$, and the relative air humidity in the range of $45-55 \%(40-60 \%)$, with the allowed daily fluctuations of $+/-5 \%$. Artefacts made of hygroscopic material call for $16-25^{\circ} \mathrm{C}$ and the stable relative air humidity (RH) of $40-60 \%$, with the fluctuations below $\pm 10 \% \mathrm{RH}$ in 24 hours within the set range. The declaration notes that guidelines for long-term display and storage of artefacts/finds should be established in line with local climate.

\section{Characteristics of Serbian climate}

The climate in Serbia is continental, conditioned by its geographical position, the terrain and other local characteristics of the region. All four seasons are present. Autumn is warmer than spring and boasts longer sunny periods. Winter is not so sharp. Spring is rainy and it abruptly turns into summer. Data on the Serbian climate are taken from the Republic Hydrometeorological Service of Serbia Report [27]. 
Between 1961 and 1990, the average air temperature in Serbia in the areas lower than $300 \mathrm{~m}$ of altitude was $10.9^{\circ} \mathrm{C}$. The highest temperature in these decades were measured in July, ranging between $37^{\circ} \mathrm{C}$ and $42.3^{\circ} \mathrm{C}$ in lower altitudes, while the lowest ranged between $-30.7^{\circ} \mathrm{C}$ and $-21.0^{\circ} \mathrm{C}$ [28]. The warmest month was July with the average temperature of $22^{\circ} \mathrm{C}$, and the coldest was January with the average temperature of $0^{\circ} \mathrm{C}$.

The annual solar insolation in Serbia is between 1500 and 2200 insolation hours. It is longest in July and August (with the largest number of insulation hours), and shortest in December and January, when the cloudiness is high.

Precipitation is inconsistent and ranges from $540 \mathrm{~mm}$ to $820 \mathrm{~mm}$ a year in lower altitudes, with more than $1000 \mathrm{~mm}$ in upper regions, which leads to the conclusion that the precipitation grows with altitude [29]. June is the rainiest month, and February or October the driest. The snow cover tends to form from November to March, most likely in January.

Typical winds in Serbia are north-west, west, and south-east winds. The latter is locally called Košava and it is a strong autumn and winter wind that brings dry and cold weather.

\section{Materials and Methods}

\subsection{Display of finds in the Visitor Centre of the Archaeological site 1a Imperial Palace Sirmium}

On the site of the ancient city of Sirmium, the present-day Sremska Mitrovica, the remains of a royal palace were uncovered in 1957, during protective excavations and mobilisation before laying foundations for a residential block-of-flats, after which the works were cancelled [30]. The research was continued in 1974 and 1976, when it was concluded that the remains belonged to a palace complex, were dated and the timeline of its construction determined [31]. The royal complex, comprising the site marked as 1a Carska Palata, was built in late $3^{\text {rd }}$ century and during most of $4^{\text {th }}$ century, when the city reached its heyday. Ancient Sirmium at the time was an important strategic point on the road connecting the eastern and the western parts of the empire. The actual position of the royal palace, close to the circus, and the similarity in architectural forms and functions with other palace complexes of the time point to the royal residence. The existence of central heating, sewage and water-supply systems, rich architectural decoration based on 350 $\mathrm{m}^{2}$-large floor mosaics with geometric ornaments [32], fragments of frescoes with floral motives, multi-coloured marble and imported porphyry, as well as other remains of material culture in the royal palace in Sirmium, are all of exceptional importance for understanding the building technique of the time, as well as the technological scope and the way of life in the ancient period on the territory of the present-day Serbia.

Architectural remains of the royal complex in Sirmium were displayed to the public in the open for 52 years, when it was decided that a structure serving the purpose of a visitor centre be raised above the site of the royal palace. The Visitor Centre was meant to display antic remnants and mosaics, and protect the site from weathering (rain, snow, the sun, wind) that causes devastation of the finds. The project was financially supported by the Serbian ministries of culture and economy and regional development. The Visitor Center was built and opened for public on $14^{\text {th }}$ December 2009, while the conservation works on mosaics have been carried out in phases and are ongoing still. The Visitor Centre building erected above the architectural remains of the royal palace was designed by architects and conservators Adrijana Škorić i Ivan Filipović (Figure 2). It is done in three levels, in the total area of 2,680 $\mathrm{m}^{2}$. On the ground floor, the entrance area comprising a souvenir shop and a coffee shop opens to a gallery from which the whole site can be seen. The ramp from the gallery leads to the lowest level with the architectural remains of the palace, however the access is currently restricted due to the ongoing conservation works on the mosaics. The gallery on the highest level offers a new point of view to the site. The structure above the architectural remains of the royal palace is not thermally insulated. It is supported on RC walls, topped with brick walls supporting the roof made of braced glued laminated lumber covered with sheet metal and polycar- 
bonate slabs by segments. Being transparent, polycarbonate slabs allowed high insolation of the interior, causing the greenhouse effect, so the interior became prone to the expansion of microorganisms (lichens) and low vegetation [33]. The situation called for additional investment in replacing the roof cover material of choice. The intervention, however, did not resolve the existing issues since the existing polycarbonate slabs were simply covered with sheet metal. Covering the site and forming the closed space above it caused the change in microclimatic conditions. That caused the architectural remains to suddenly dry off, at the same time increasing the humidity in the closed part of the site and in certain zones on display. The remains of the royal palace have been permanently compromised. Unbalanced microclimate, temperature and humidity fluctuations, and the side effects in the form of microorganisms and low vegetation growing on the finds, pose the main hazard for the preservation as indicators of compromised cultural heritage. Monitoring microclimatic conditions in the Visitor Centre would determine the values of the microclimatic parameters, which would then serve as the basis for assessing the risks for further display of the finds in such conditions. Mosaics M2, M23 and M34 will also be subjected to monitoring to determine the level of their contamination.

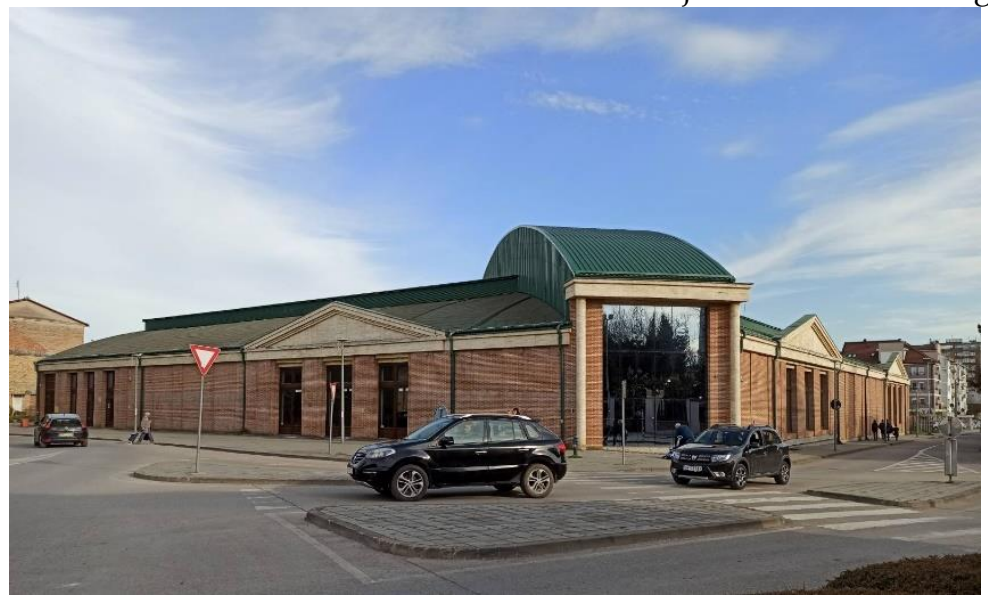

(a)

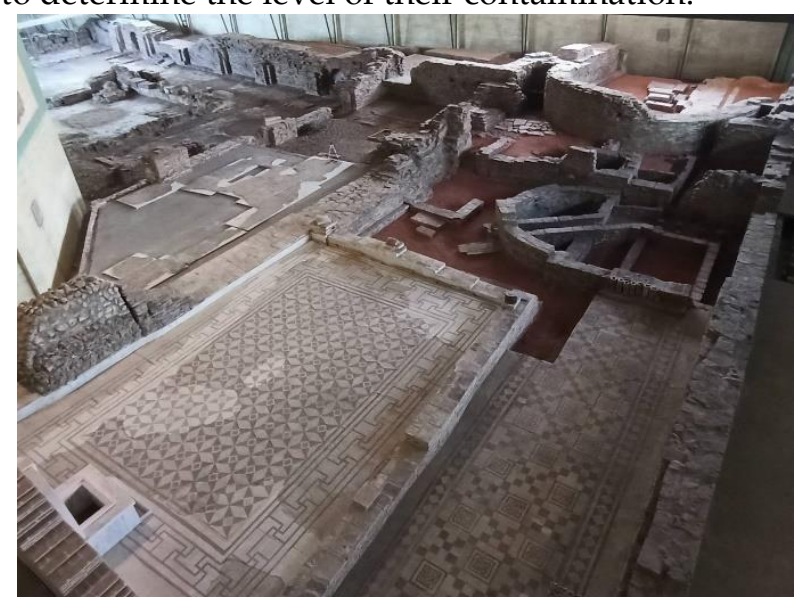

(b)

Figure 2. Visitor Centre of the Archaeological site 1a Imperial Palace Sirmium: (a) viewed from the outside; (b) the interior. Source: A.Ugrinović.

\subsection{Microclimate monitoring}

In the Visitor Centre of the Archaeological site 1a Imperial Palace Sirmium, continuous measurements of indoor and outdoor values of microclimatic parameters of temperature and relative air humidity were performed from February to April. The reading interval was 30 minutes. The data were collected by the Testo $174 \mathrm{~h}$ device (Figure $3 \mathrm{a}$ ) and the PCE-FWS-20 meteorological station (Figure 3b).

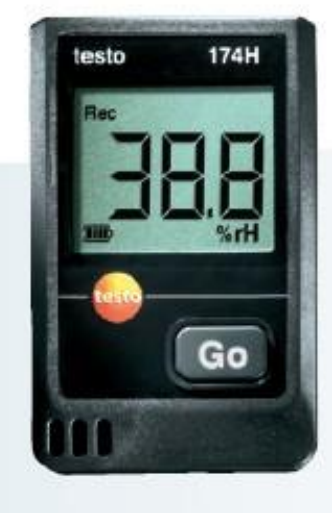

(a)

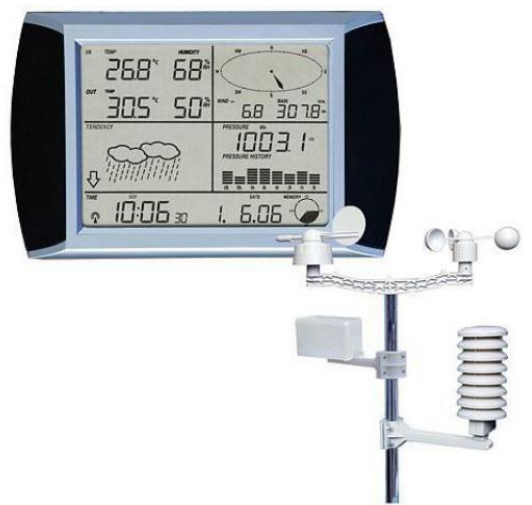

(b) 
Figure 3. The devices used for monitoring microclimate: (a) Data logger Testo 174h, Source: [34]; (b) Meteorological station PCE-FWS-20. Source: [35].

The indoor values of microclimate parameters were read by the Testo $174 \mathrm{~h}$ device. This device has a measuring range from -20 to $+70^{\circ} \mathrm{C}$ (with $0.5^{\circ} \mathrm{C}$ accuracy) and from 0 to $100 \%$ (accuracy of $3 \% \mathrm{RH}$ ). The memory capacity of the data logger TESTO $174 \mathrm{~h}$ is 16000 readings. Testo data loggers are placed at $30 \mathrm{~cm}$ (DL1) and at $350 \mathrm{~cm}$ from the ancient mosaic floor (DL2) in order to determine the vertical distribution of temperature and relative air humidity.

The meteorological station PCE-FWS-20 is placed on the south-eastern gable wall of the Visitor Centre for the purpose of measuring outdoor microclimate. The memory display that stores the measured data and is via radio waves connected with the meteorological station is on the interior side of the property, on the south-eastern wall, at the upper-level gallery. The vertical distance of the meteorological station display from the level with the Imperial Palace architectural remains is about $9 \mathrm{~m}$. The PCE-FWS-20 instrument for reading outdoor values of temperature and relative air humidity measures the range from $-40^{\circ} \mathrm{C}$ to $65^{\circ} \mathrm{C}$ and from 10 to $90 \%$, while the traceable indoor microclimate values range from 0 to $+50^{\circ} \mathrm{C}$ and from 10 to $90 \%$.

\subsection{Mycological analyses}

\subsubsection{In situ optical micrscopy}

The studied mosaics were investigated at the site, using Delta Optical Smart 5MP PRO digtal USB microscope (Delta optical). In situ microscopy was applied directly on areas with visible biodeterioration symptoms. Image processing was carried out via Delta Optical SmartAnalysis Pro softvare.

\subsubsection{Sampling methods}

Non-invasive adhesive tape was applied to the mosaics' surface and, in order not to damage the investigated object, removed with a steady force [36]. Samples were then attached to microscopic slides and preserved in sterile container for further microscopic analyses.

In order to sample viable fungal propagules, selected areas (approximately $10 \mathrm{~cm} 2$ surface) with biodeterioration symptoms were wiped with sterile cotton swabs and inoculated and transferred in sterile bags to laboratory. Samples were inoculated on Malt extract agar (MEA) and incubated in thermostat (UE 500, Memmert) on $25^{\circ} \mathrm{C}$ for 7 days. After incubation period, colonies were enumerated to establish the number of colony forming units per units of surfce ( $\mathrm{CFU} \mathrm{cm}-2)$ and pure fungal cultures were obtained from primary isolates.

Aeromycological sampling was carried out by Koch's sedimentation method [37]. Petri plates $(9 \mathrm{~cm} \varnothing)$ with MEA medium were opened and exposed for 15 minutes in the proximity of the studied mosaics. Afterwards, petri plates were closed, sealed with parafilm and transferred in sterile bags to laboratory. After incubation period $\left(25^{\circ} \mathrm{C}, 7\right.$ days $)$, viable colonies were enumerated and total fungal load ( $\mathrm{CFU}$ m-3 of air) was evaluated according to formula $[38,39]$ :

$$
\mathrm{N}=5 \times \mathrm{a}(\mathrm{bt})^{-1} \times 10^{4}
$$

$\mathrm{N}=$ total number of $\mathrm{CFU} \mathrm{\textrm {m } ^ { - 3 }}, \mathrm{a}=$ number of colonies per Petri dish, $\mathrm{b}=$ dish square centimeter, $\mathrm{t}=$ exposure time $(\mathrm{min}$.)

\subsubsection{Fungal identification}

Adhesive tape samples were mounted in LactophenolCottonBlue-glycerol mixture and observed under a light microscope. Isolates obtained via both cotton swabs and aeromycological sampling were identified based on macromorphology of 7 days old colonies and micromorphology of reproductive structures, observed by optical micro- 
scope Zeiss Axio Imager M.1 with AxioVision Release 4.8.1 software. Identification was performed using identification keys [40,41, 42].

\section{Rezultati mikroklimatskog monitoringa i mikrobioloških ispitivanja Results of microclimate monitoring and microbiological research}

\subsection{Microclimate in the Visitor Centre of Archaeological site 1a Imperial Palace Sirmium}

The microclimate monitoring results for the period between $8^{\text {th }}$ February and $5^{\text {th }}$ April 2021 are shown for each measurement device respectively. The values read from Testo data logger DL1 (placed at $30 \mathrm{~cm}$ from the floor mosaic elevation) and from DL2 (placed at $350 \mathrm{~cm}$ from the floor mosaic elevation) are shown in Figure 4. The data were processed by Testo Comfort Software Basic 5.0. The mean temperature value during the monitoring period was $8^{\circ} \mathrm{C}$ (DL1) and $8.21^{\circ} \mathrm{C}$ (DL2), while the average relative air humidity was about 75\% (DL1) and 73.55\% (DL2). The maximum temperature value was recorded on $1^{\text {st }}$ April and it amounted to $16^{\circ} \mathrm{C}$ (DL1) and $16.90^{\circ} \mathrm{C}$ (DL2), while the lowest temperature was read on $14^{\text {th }}$ February and was $0.40^{\circ} \mathrm{C}$ (DL1) and $0.30^{\circ} \mathrm{C}$ (DL2). The highest relative humidity value was recorded on $11^{\text {th }}$ February and was $93.40 \%$ (DL1) and 93.50\% (DL2), while the lowest relative humidity was 51.70\% (DL1) and 48.70 (DL2). Based on the microclimate monitoring results indoors, it may be stated that the values read from devices DL1 and DL2 are approximately the same. However, it is evident that the temperature is increasing and the relative humidity decreasing with height. The greatest daily temperature oscillation was $6^{\circ} \mathrm{C}$, while the oscillations of relative air humidity were as high as $30 \%$ even daily. According to the daily oscillations of microclimatic parameters envisaged in the recommendations and guidelines for the conservation of museum collections, relative air humidity oscillations are much higher than the recommended (max. $+/-10 \%$ ). During the longer period of temperature measurement, daily variations were acceptable and within the permitted range. Relative air humidity was above the recommended limit value of $60 \%$. No temperature values below 0 were recorded at measurement positions and therefore the materials of which the mosaic structure is made were not exposed to stress due to the freeze-thaw cycle.

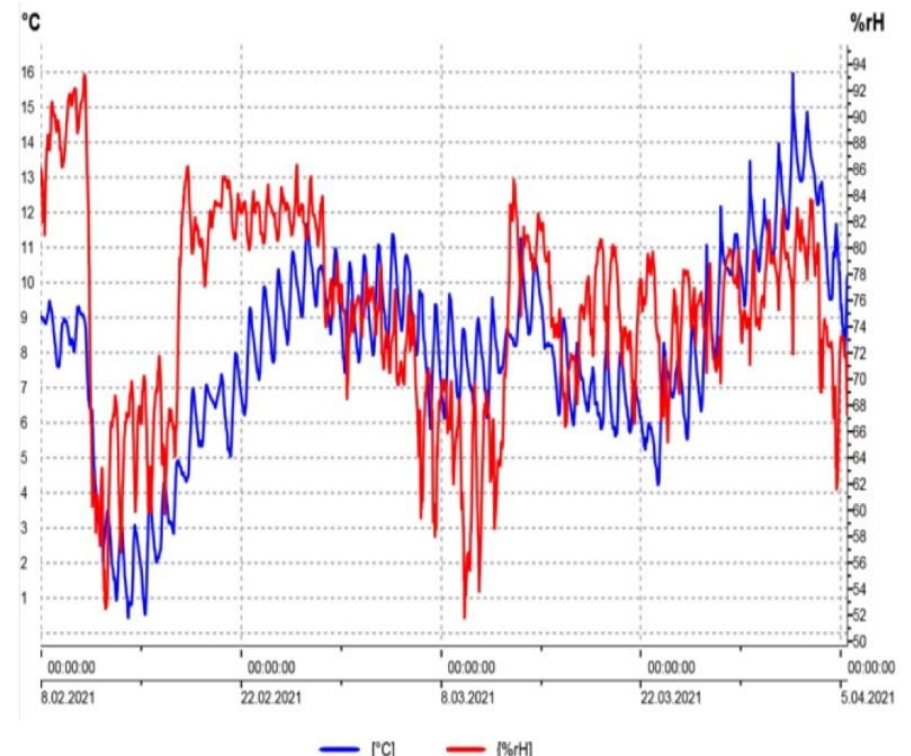

(a)

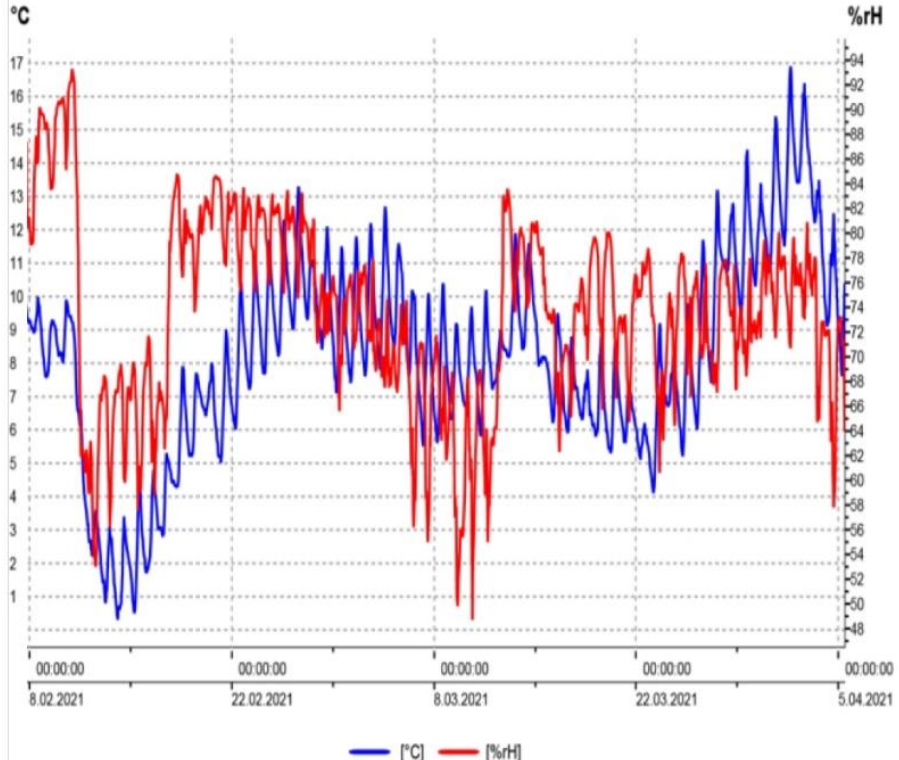

(b)

Figure 4. Graphic representation of temperature and relative air humidity inside the Visitor Centre of the Imperial Palace: (a) The values read from the data logger DL1 (placed at $30 \mathrm{~cm}$ above the floor mosaic); (b) The values read from the data logger DL2 (placed at $3.50 \mathrm{~m}$ above the floor mosaic). Source: A.Ugrinović and B. Sudimac.

From the meteorological station PCE-FWS-20, the outdoor values of temperature and relative air humidity were read, and indoor parameter values were measured at $8 \mathrm{~m}$ 
from the ancient mosaic floor elevation. The charts show comparative outdoor and indoor values of microclimatic parameters of temperature (Figure 5) and relative air humidity (Figure 6). The data were processed by EasyWeather. The outdoor temperature in the measurement period ranged from $-7.6^{\circ} \mathrm{C}$ to $26.2^{\circ} \mathrm{C}$, while inside the Imperial Palace it was from $4.2^{\circ} \mathrm{C}$ do $18.2^{\circ} \mathrm{C}$. Relative humidity varied from $15 \%$ to $99 \%$ indoors and from $38 \%$ to $79 \%$ outdoors. Based on the monitoring and comparative analysis of indoor and outdoor climate conditions, it was established that indoor variations of relative air humidity and temperature were substantially smaller, but the changes outdoors affected the indoor microclimate.

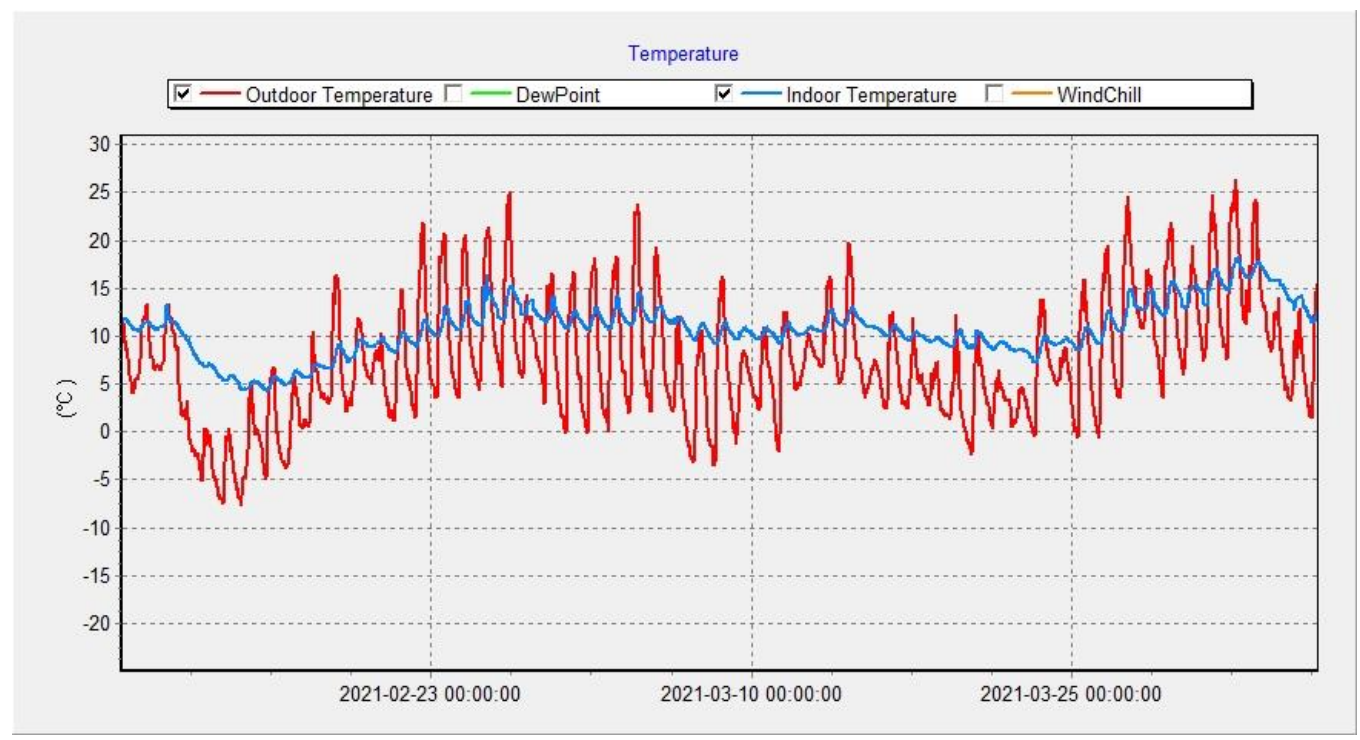

Figure 5. Graphic representation of temperature inside and outside the Imperial Palace Visitor Centre. Source: A.Ugrinović and B. Sudimac.

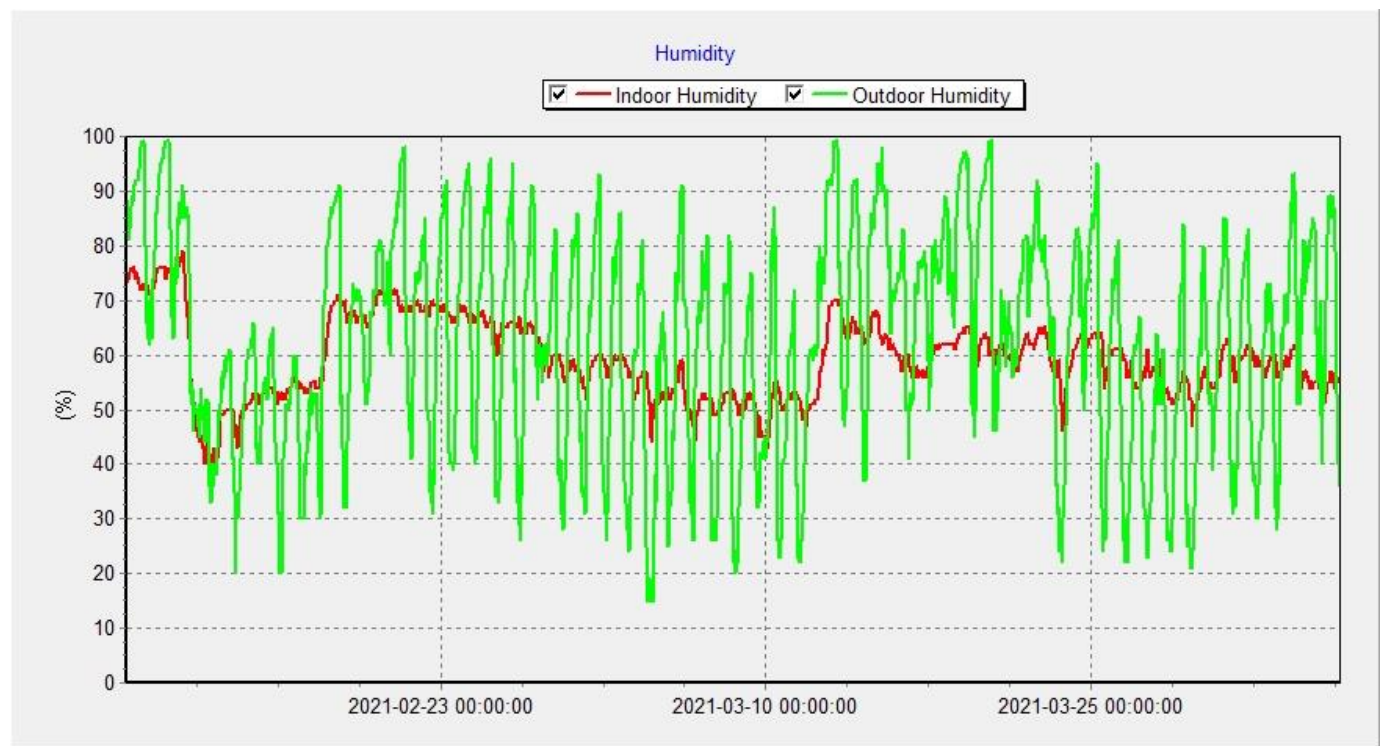

Figure 6. Graphic display of relative humidity inside and outside the Imperial Palace Visitor Centre. Source: A.Ugrinović and B. Sudimac.

\subsection{Biological colonization of mosaics}

In situ optical microscopy provided better insight into mosaic's surface. Stone surface was deteriorated with visible cracks and detached stone fragments (Figure 7). M23 and M34 mosaics were intensively overgrown with mosses. Additionally, thalli of epilithic lichens were documented on the M2 mosaic. 

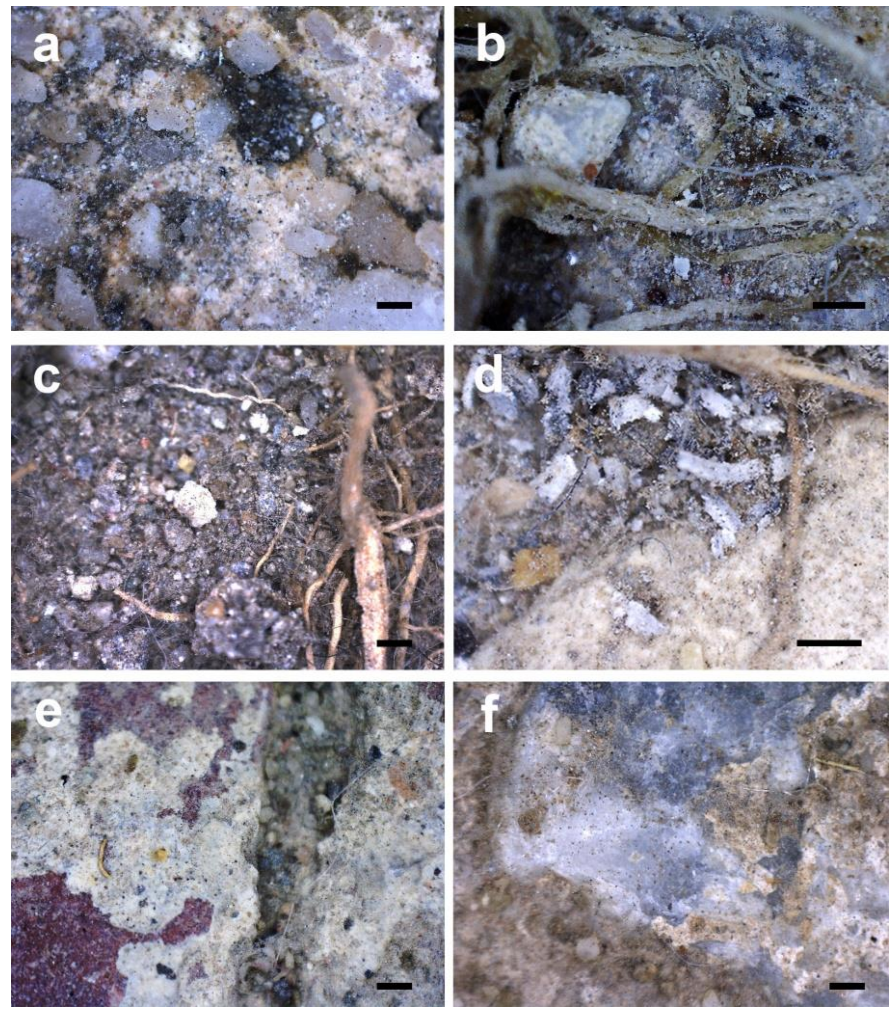

Figure 7. In situ optical microscopy of the deteriorated mosaics' surface with visible moss rhizoids and lichen thalli: a,b) M23; c,d) M34; e,f) M2. Scale bar: 1 mm. Source: Ž. Savković.

Examination of adhesive tapes revealed abundant microbiological contamination of M34 and M2 objects (Figure 8). Various types of fungal propagules were detected, most frequently melanized conidia of Alternaria, Cladosporium and Epicoocum species along with unidentified dyctiospores, scolecospores, chlamydospores and ascospores. Additionally, various plant tissues, trichomes, pollen grains and green algae cells were detected along with occasional nematode specimens and hairs of animal origin. Conversely, adhesive tape examination of M23 object showed no visible microbiological structures.

Sterile cotton swabs samples provided further insight into the composition of viable microbiological community (Table 1). The lowest number of microorganisms was isolated from M23 mosaic (only $40 \mathrm{CFUcm}^{-2}$ ) while abundance of microorganisms on M34 and M2 objects was significantly higher (164 $\mathrm{CFUcm}^{-2}$ and $208 \mathrm{CFUcm}^{-2}$, respectively). Bacteria were most frequent cultivable microorganisms in all samples while fungi were represented with species of seven genera: Alternaria, Aspergillus, Cladosporium, Fusarium, Penicillium, Rhizopus and Scopulariopsis. Among them, Cladosporium and Penicillium species were most frequently present (Table 1 ). 

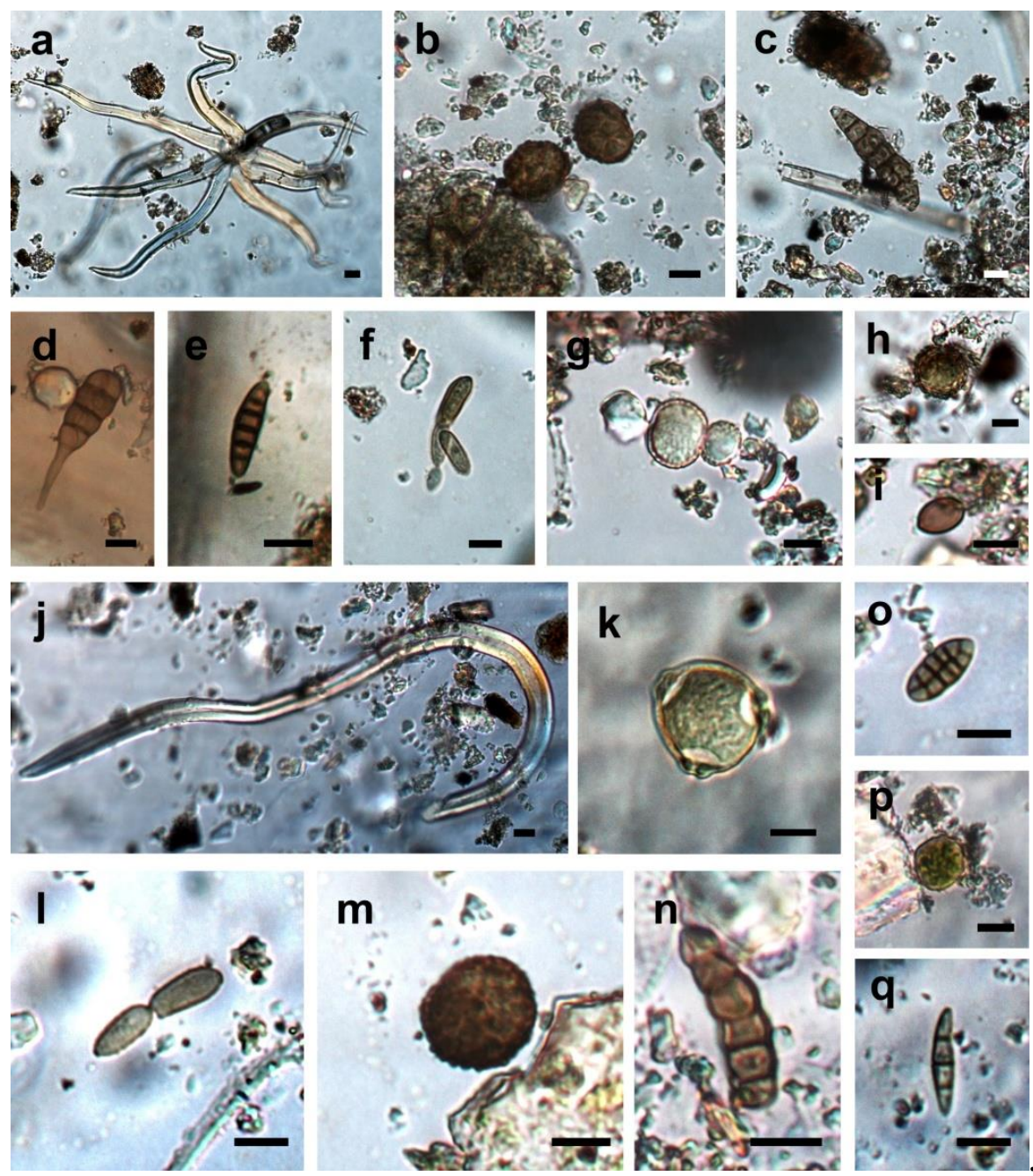

Figure 8. Biological structures detected on the mosaics' surface detected via adhesive tape (M34: a-i; M2: j-q): a) plant trichome; b, m) Epicoccum nigrum conidia; c,d) Alternaria spp. conidia; e) melanized scolecospore; f,l) Cladosporium spp. conidia; g,h) chlamydospores; i) ascospore; j) nematode; k) pollen grain; o) melanized dyctiospore; $n, q)$ scolecospores; $p$ ) green alga. Scale bar: $10 \mu \mathrm{m}$. Source: Ž. Savković.

Table 1. Fungi isolated from investigated mosaics via sterile cotton swabs sampling. Source: Ž. Savković.

\begin{tabular}{|c|c|c|c|}
\hline Sampling site & \multicolumn{2}{|c|}{ Detected taxa } & CFU $\mathrm{cm}^{-2}$ \\
\hline \multirow{6}{*}{ M23 } & Penicillium spp. & 4 & \multirow{6}{*}{40} \\
\hline & Fusarium sp. & 3 & \\
\hline & Alternaria spp. & 2 & \\
\hline & Scopulariopsis sp. & 1 & \\
\hline & Cladosporium sp. & 1 & \\
\hline & Bacteria & 29 & \\
\hline \multirow{4}{*}{ M34 } & Aspergillus niger & 3 & \multirow{4}{*}{164} \\
\hline & Penicillium spp. & 3 & \\
\hline & Cladosporium sp. & 12 & \\
\hline & Bacteria & 142 & \\
\hline \multirow{4}{*}{ M2 } & Aspergillus niger & 2 & \multirow{4}{*}{208} \\
\hline & Cladosporium spp. & 15 & \\
\hline & Rhizopus sp. & 1 & \\
\hline & Bacteria & 190 & \\
\hline
\end{tabular}




\subsection{Airborne microorganisms}

Aerobiological sampling demonstrated $1572 \mathrm{CFU}$ m-3 (equivalent to 30 colonies on a petri plate) at the sampling site adjacent to the M23 mosaic and 2883 CFUm-3 (equivalent to 55 colonies on a petri plate) adjacent to M34. Most of CFUs belonged to bacteria and only few Cladosporium colonies were documented.

\section{Discussion}

The microclimate monitoring results in the Visitor Centre of the Archaeological site 1a Imperial Palace Sirmium indicate that the environmental conditions deviate from the recommended values of the microclimatic parameters for the conservation of museum collections in the AICCM Declaration and the document on hygroscopic material stability [26]. During almost the entire measurement period, relative air humidity was above the recommended value of $60 \%$, with the greatest daily oscillations of up to $30 \%$. The temperature was mostly below the recommended lower value of $15^{\circ} \mathrm{C}$, with the maximum daily variations of up to $6^{\circ} \mathrm{C}$. At the lower measurement positions, closer to the Imperial Palace floor mosaics remains, relative humidity varied within the permitted range on $12^{\text {th }}$ February, and from $6^{\text {th }}$ to $12^{\text {th }}$ March and on $4^{\text {th }}$ April 2021, while the temperature above $15^{\circ} \mathrm{C}$ was recorded as late as on $1^{\text {st }}$ April. It has been established that the relative air humidity values are lower at a greater height, i.e. greater distance from the elevation of the finds. Looking at the vertical distribution of relative air humidity and temperature, it transpires that relative air humidity decreases while temperature increases from the architectural remains of the Imperial Palace towards the roof structure of the Visitor Centre. In that manner, the interdependence of relative air humidity and temperature has been confirmed.

Although the temperature in the Imperial Palace during the monitoring period was mostly below the recommended range according to ASHRAE [25] and the authorities in this area, it does not pose a problem because it has turned out that the artifacts exposed to lower temperatures are more stable. This does not slow down the natural aging of the finds. It should be noted that temperature does not fall below $0^{\circ} \mathrm{C}$ and freeze-thaw cycle is therefore avoided, and it is a known fact that these processes have an adverse effect on inorganic, porous hygroscopic materials that form the mosaic structure [7]. However, it should also be considered that low temperatures are not convenient for the visitors' stay.

A greater problem for the conservation of the finds is the high value of relative air humidity and large daily oscillations. The causes for such high relative air humidity in the Visitor Centre should be sought mainly in the site conditions, as well as in the applied materialisation and non-existence of natural ventilation, i.e. the possibility of airing the site. The proximity of the Sava River, the high level of ground waters and the presence of the Renney wells on the site may be the main reasons for the increased humidity.

The results of the microbiological analyses, the contamination degree of the mosaic and the presence of microorganisms in the air have ensured an insight into the current situation on the site in order to establish the biological deterioration hazard of the finds and assert the necessity to conserve the mosaics for preservation purposes. Applied microscopical techniques and cultivation methods showed higher biological colonisation of M2 and M34 mosaics compared to M23, which was demonstrated by lower CFU counts per surface, as well as adhesive tape examination. This can be attributed to the fact that M23 was recently cleaned during the conservation treatment and organic material from it removed. About 50 years have passed since the conservation of M2 and M34 mosaics and extensive contamination is expected. According to the current state, these mosaics need to be re-conserved. In situ optical microscopy has only recently begun to be used for the investigation of cultural heritage made of stone and is credited as a rapid and practical method for biological screening. Furthermore, it is considered to be a cost-effective tool that can perform high level analyses [43].

Stone substrata are considered oligothrophic environments, but nevertheless aerial depositions and the presence of photothrophic organisms such are algae, cyanobacteria 
and lichens could enrich stone surface with nutrients which are neccesary for the development of heterothrophic microorganisms, i.e. bacteria and fungi [44]. Presence of various fungal propagules on the stone surface and isolates obtained via sterile swabs suggests potential biodeterioration action. Namely, fungi are able to deteriorate stone both mechanically and chemically. Mechanical deterioration is demonstrated by active hyphal growth and penetration. On the other hand, chemical biodeterioration mechanisms of stone include secretion of acidic metabolites and production of pigments $[45,46]$. Some of these alterations can lead to both structural and aesthetic changes to the monument and can be irreversable [45,47]. It is also asserted that biodeterioration actions lead to the changes of thermal-hygric properties of the stone [48]. Species of genera Aspergillus, Alternaria, Penicillium and Fusarium are frequently detected on lithic substrata $[44,49]$ which is in correspondence with our findings. Recent studies carried out on ancient Roman stela [43] and Portugese king tomb [50] confirmed presence of the mentioned taxa on limestone and also demonstrated biodegradation potential of selected fungal isolates.

Concentration of airborne fungal propagules is dependent on different environmental factors such as temperature and relative air humidity, as well as the availability of nutrients [51, 52]. Cumulative effects of these factors are complex, and it is generally hard to determine how individual factors contribute to the abundance of biological propagules in the air [52]. In the temperate regions, maximum concentrations of fungal propagules is documented during summer and early autumn, i.e. seasons when relative air humidity is higher [53]. These are the reasons why it is necessary to continue air sampling in other seasons of the year. To this day, there are no universally accepted standards for microbial air contamination. Some sources propose that values above $1000 \mathrm{CFU} \mathrm{\textrm {m } ^ { - 3 }}$ are considered as high $[54,55]$ while other ascertain a threshold of $1000 \mathrm{CFU} \mathrm{\textrm {m } ^ { - 3 }}$ for bacteria and 3000 CFU m$~^{-3}$ for fungi [56]. Nevertheless, increased levels of airborne fungal propagules are considered to pose a threat to cultural heritage, especially in enclosed and semi-enclosed spaces [57]. Therefore, a systematic monitoring of air quality is essential on the cultural heritage premises.

\section{Conclusions}

After the conducted microclimatic and microbiological research, it has been confirmed that high values and large daily oscillations of relative air humidity are the key factors for the devastation of finds in the Visitor Centre of the Archaeological site 1a Imperial Palace Sirmium. In order to improve the existing microclimatic conditions and ensure the sustainable use of the property, passive measures are recommended, before all the upgrade of thermal characteristics of the facility and provision of natural ventilation. The analysis of the passive measures efficiency for improving the existing microclimatic regime is not the subject matter of this paper and it will be in focus of the next research.

Examining the impact of the microclimatic conditions on the stability of the mosaics in the Visitor Centre of the Archaeological site 1a Imperial Palace Sirmium is the starting point for establishing the optimal microclimatic regime both for the comfortable stay of visitors and for the conservation of the finds. Since the measurements were taken in a short period of time to get an insight into the microclimatic regime in all the seasons of the year, it is necessary to continue the environmental microclimatic monitoring.

Having in mind that the microclimatic aspect has been neglected in the design of protective structures on archaeological sites although it is an important factor in the conservation and preservation of the mosaics, a broader contribution of the research is based on the use of the research results as a starting point for the introduction of microclimate monitoring as a mandatory procedure inside protective structures, as well as in designing new solutions for the display of material finds.

Author Contributions: Conceptualization, A.U., B.S. and Ž.S.; methodology, A.U., B.S. and Ž.S.; software, A.U. and B.S.; validation, A.U., B.S. and Ž.S.; formal analysis, A.U., B.S. and Ž.S.; investigation, A.U., B.S. and Ž.S.; resources, A.U., B.S. and Ž.S.; data curation, A.U. and Ž.S.; writ- 
ing-original draft preparation, A.U. and Ž.S.; writing - review and editing, B.S. and Ž.S.; visualization, A.U. and Ž.S.; supervision, B.S.; project administration, A.U.; funding acquisition, B.S.

Funding: This paper was written as a part of the project "Research on Climate Change and its Impact on the Environment - Monitoring of Impacts, Adaptation and Mitigation"(43007), financed by the Serbian Ministry of Education, Science and Technological Development under the program of Integrated and Interdisciplinary Research and the project "Research on the impact of microclimatic environmental conditions on the preservation of finds in the Visitor Centre of the Archaeological site 1a Imperial Palace Sirmium", financed by the Serbian Ministry of Culture and Information.

Acknowledgments: We would like to thank the Ministry of Education, Science and Technological Development of the Republic of Serbia and the University in Belgrade, the Faculty of Architecture, for funding this paper. We express special gratitude to the Institute for the Protection of Cultural Monuments of Serbia - Belgrade, for the issued technical protection measures, and the Institute for the Protection of Cultural Monuments of Sremska Mitrovica for recognising the importance of microclimate monitoring in the Visitor Centre of the Archaeological site 1a Imperial Palace Sirmium and for supporting its implementation.

Conflicts of Interest: The authors declare no conflict of interest.

\section{References}

1. Ugrinović, A. Zaštitne konstrukcije u funkciji prezentacije ostataka antičkog nasleđa. U Zborniku radova VII konferencije Zavoda za zaštitu spomenika kulture grada Beograda: Kulturni predeo, Beograd, Srbija 2016, pp. 116-127.

2. Ugrinović, A.; Krstić-Furundžić, A. Technological solutions for covering archaeological sites in order to present mosaics in situ - case studies. In Proceedings of the 6th International Academic Conference on Places and Technologies: Keeping up with Technologies to turn built heritage into the places of future generations; Molnár, T., Krstić-Furundžić, A., Vaništa Lazarević, E., Djukić, A., Medvegy, G., Bachmann, B., Vukmirović, M., Eds.; 613-620. University of Pécs Faculty of Engineering and Information Technology, Pécs, Hanguary, 2019; pp. 613-620, ISBN: 978-963-429-401-6.

3. Pensabene, P.; Gallocchio, E. The Villa del Cásale of Piazza Armerina. Penn Museum 2011, 53, No. 2, 29-37, (35). Available online: https://www.penn.museum/documents/publications/expedition/PDFs/53-2/pensabene.pdf (accessed on 12 June 2021).

4. Nicholas, P.; Price, S.; Jokilehto, J. The decision to shelter arheological sites: Three case-studies from Sicily. Conservation and management of arheological sites 2001, Volume 5, pp. 19-34, ISSN 1350-5033.

5. Rizzi, Gionata. Sheltering the mosaics of Piazza Armerina: issues of conservation and presentation. Heritage, Conservation, and Archaeology, AIA Site Preservation Program, Arheological Institute of America, 2008, 1-3. Available online: https://www.archaeological.org/pdfs/site_preservation_Oct_08.pdf (accessed on 12 June 2021).

6. Vozikis, T.K. Protective Structures on Archaeological Sites in Greece, in WSEAS Int. Conf. on Environment, ecosystems and development, Venice, Italy, November 2-4, 2005, pp. 122-123. Available online: http://www.wseas.us/e-library/conferences/2005venice/papers/508-305.pdf (accessed on 12 June 2021).

7. European Committee for Standardization (CEN). Conservation of Cultural Property. Specifications for Temperature and Relative Humidity to Limit Climate-Induced Mechanical Damage in Organic Hygroscopic Materials, Standard EN 15757; CEN: Brussels, Belgium, 2010, pp. 9.

8. Schito, E.; Testi, D.; Grassi, W. A Proposal for New Microclimate Indexes for the Evaluation of Indoor Air Quality in Museums. MDPI Buildings 2016, 4:41, 1-15, doi:10.3390/buildings6040041

9. D'agostinoa, V. ; Alfanob, F. R.A. Palella, B. I.; Riccioc, G. The museum environment: A protocol for evaluation of microclimatic conditions, Energy and Buildings 2015, 95, 124-129, Available online: http://dx.doi.org/10.1016/j.enbuild.2014.11.009 (accessed on 18 June 2021).

10. G. Pavlogeorgatos. Environmental parameters in museums. Building and Environment 2003, 38, 1457 - 1462, Available online: https://doi.org/10.1016/S0360-1323(03)00113-6 (accessed on 18 June 2021).

11. Christensen, J.E.; Kollias, C.G. Hygrothermal evaluation of a museum storage building based on actual measurements and simulations. 16th International Building Physics Conference, IBPC 2015. Energy Procedia 2015, 78, 651 - 656, doi: 10.1016/j.egypro.2015.11.051

12. Živković, V.; Džikić, V. Return to basics-Environmental management for museum collections and historic houses. Energy and Buildings 2015, 95, 116-123, Available online: http://dx.doi.org/10.1016/j.enbuild.2014.11.023 (accessed on 18 June 2021).

13. Kotterer,M.; Großeschmidt, H.; Boody, P. F.; Herausgeber W. K.; Eds. Klima in Museen und historischen Gebäuden: Die Temperierung / Climate in Museums and Historical Buildings: Tempering. Publisher: Wissenschaftliche Reihe Schonbrunn, Band 9, Vienna, Austria, 2004; ISBN 3-901 568-51-4.

14. Bonora, A.; Fabbri, K.; Pretelli M. Study of the indoor microclimate for preventive conservation and sustainable management of historic buildings. Energy Efficiency in Historic Buildings 2018, pp. 381-390, Available online: https://www.diva-portal.org/smash/get/diva2:1296990/FULLTEXT01.pdf (accessed on 1 August 2021)

15. Bonora, A.; Fabbri, K.; Pretelli M. Environmental microclimate management and risk in the UNESCO World Heritage sites of Villa Barbaro Master (Italy). In The International Archives of the Photogrammetry, Remote Sensing and Spatial Information Sciences, Volume XLII-2/W11, 2019, Proceedings of The GEORES 2019 - 2nd International Conference of Geomatics and Res- 
toration, Milan, Italy, 8-10 May 2019; 269-276. Available online: https://doi.org/10.5194/isprs-archives-XLII-2-W11-269-2019 (accessed on 1 August 2021)

16. Fabbri, K.; Pretelli M.; Bonora, A. The Study of Historical Indoor Microclimate (HIM) to Contribute towards Heritage Buildings Preservation. Heritage 2019, Volume 2, 2287-2297, doi:10.3390/heritage2030140.

17. Fabbri, K.; Pretelli M. Heritage buildings and historic microclimate without HVAC technology: Malatestiana Library in Cesena, Italy, UNESCO Memory of the World. Energy and buildings 2014. 76, 15-31. Available online: http://dx.doi.org/10.1016/j.enbuild.2014.02.051 (accessed on 1 August 2021).

18. Živković, V. Regulacija klimatskih uslova u depou mozaika u galeriji fresaka, Diana 2008, 12, 117-123, USSN 1451-1800.

19. Kompatscher, K.; Kramer, R.P.; Ankersmit, B.; Schellen, H.L. Intermittent conditioning of library archives: Microclimate analysis and energy impact. Building and Environment 2019, 147, 50-66. Available online: https://doi.org/10.1016/j.buildenv.2018.10.013 (accessed on 4 August 2021).

20. Valero, M.Á.; Merello, P.; Navajas, Á.F.; García-Diego, F.J. Statistical Tools Applied in the Characterisation and Evaluation of a Thermo-Hygrometric Corrective Action Carried out at the Noheda Archaeological Site (Noheda, Spain). Sensors 2014, 14, 1665-1679, doi:10.3390/s140101665.

21. Merello, P.; García-Diego, F.J; Zarzo, Manuel. Microclimate monitoring of Ariadne's house (Pompeii, Italy) for preventive conservation of fresco paintings. Chemistry Central Journal 2012, Volume 6:145, pp. 1-16, doi:10.1186/1752-153X-6-145.

22. Scatigno C., Gaudenzi, S. Sammartino, M.P. Visco, G. A microclimate study on hypogea environments of ancient roman building. Science of the Total Environment 2016, 566-567, 298-305, Available online: https://doi.org/10.1016/j.scitotenv.2016.05.050 (accessed on 4 August 2021).

23. European Committee for Standardization (CEN). Conservation of Cultural Property. Specifications for Temperature and Relative Humidity to Limit Climate-Induced Mechanical Damage in Organic Hygroscopic Materials, Standard EN 15757; CEN: Brussels, Belgium, 2010, p. 9.

24. Thompson, Garry. The museum environment, 2nd ed.; Butterworths-Heinmann: London, England, 1978, p. 268.

25. ASHRAE, Museums libraries and archives, in: 2011 ASHRAE Handbook.Heating, Ventilating, and Air-Conditioning Applications, SI ed., American Society of Heating, Refrigerating and Air-Conditioning Engineers, Atlanta, 2011, (Chapter 23).

26. ICOM-CC (International Council of museum - Committee for conservation). Environmental Guidelinesl ICOM-CC and ICC Declaration; ICOM-CC: Melbourne, Australia, $2014 . \quad$ Available online:. http://www.icom-cc.org/332/-icom-cc-documents/declaration-on-environmental-guidelines/\#.YMSMBqgzaUn (accessed on 6 May 2021).

27. Available online: http://www.hidmet.gov.rs/data/klimatologija static/latin/Klima Srbije.pdf (accessed on 9 August 2021)

28. Available online: http://www.hidmet.gov.rs/data/klimatologija static/latin/Temperaturni rezim u Srbiji.pdf (accessed on 9 August 2021).

29. Available online: http://www.hidmet.gov.rs/data/klimatologija static/latin/Padavinski rezim u Srbiji.pdf (accessed on 9 August 2021).

30. Jeremić, M. Sirmijum grad na vodi-Razvoj urbanizma i arhitekture od I do VI veka. Arheološki institut: Beograd, Srbija, 2016; p. 217, ISBN 978-86-6439-002-6.

31. Werner, M. R. Imperial palace complex Sirmium. Zavod za zaštitu spomenika kulture Sremska Mitrovica: Sremska Mitrovica, Srbija, 2009; pp. 26-27, ISBN 978-86-906655-6-3.

32. Lučić, B. Novi nalazi mozaika sa lokaliteta 1A - Carska palata Sirmijuma. Spomenica Istorijskog arhiva "Srem" 2015, 14, 94-114.

33. Smičiklas, N.; Protić, M.; Jelikić, A. The archeological site of Sirmium, Sremska Mitrovica, Serbia: Condition survey and development of a conservation and maintance program for the mosaics. In Managing archeological sites with mosaics: From real problems to practical solutions, The 11th conference of the International Committee for the Conservation of Mosaics, Meknes and Volubilis, 24-27 October 2011; Michaelides, D.; Guimier-Sorbets, A.M. Eds.; EDIFIR-Edizioni: Firenze, Italy, 2017, pp. 225-242, Available online: https://iccm-mosaics.org/wp-content/uploads/2017/11/MEKNES-Proceedings.pdf (accessed on 12 June 2021)

34. Available online: https://testo.rs/etaloniranje/testo-174h-mini-temperature-and-humidity-data-logger/ (accessed on 6 August 2021)

35. Available online: https://www.pce-iberica.es/manuales/manual-estacion-meterologica-pce-fws-20n-v2.pdf (accessed on 6 August 2021).

36. Urzi, C.; de Leo, F. Sampling with adhesive tape strips: an easy and rapid method to monitor microbial colonization on monument surfaces. Journal of Microbiological Methods 2001, 44, 1-11, doi: 10.1016/S0167-7012(00)00227-X.

37. Knežević-Vukčević J.; Simić D. Metode u mikrobiologiji; Univerzitet u Beogradu, Biološki Fakultet: Beograd, Srbija, 2006.

38. Omelyansky, V.L. Manual in Microbiology, USSR Academy of Sciences: Moscow, Leningrad, 1940.

39. Viani, I.; Colucci, M. E.; Pergreffi, M.; Rossi, D.; Veronesi, L.; Bizzarro, A.; Capobianco, E.; Affanni, P.; Zoni, R.; Saccani, E.; Albertini, R.; Pasquarella, C. Passive air sampling: the use of the index of microbial air contamination. Acta bio-medica: Atenei Parmensis 2020, 91(3-S), 92-105, Available online: https://doi.org/10.23750/abm.v91i3-S.9434 (accessed on 12 July 2021)

40. Ellis, M.B.; Ellis, J.P. Microfungi on land plants: an identification handbook, new enlarged edition. Slough, Richmond. 1997; ISBN 0855462469.

41. Watanabe, T. Soil and seed fungi. Morphologies of cultured fungi and key to species; Crc press: London, England, 2002; ISBN 978-1-4398-0419-3.

42. Samson, R.A.; Houbraken, J.; Thrane, U.; Frisvad, J.C.; Andersen, B. Food and indoor fungi, $1^{\text {st }}$ edition; CBS-KNAW Fungal Biodiversity Centre: Utrecht, Netherlands, 2010. 
43. Savković, Ž.; Unković, N.; Stupar, M.; Franković, M.; Jovanović, M.; Erić, S.; Šarić, K.; Stanković, S.; Dimkić, I.; Vukojević, J.; Ljaljević Grbić, M. Diversity and biodeteriorative potential of fungal dwellers on ancient stone stela. International Biodeterioration E Biodegradation 2016, 115, 212-223, doi: 10.1016/j.ibiod.2016.08.027.

44. Ortega-Morales, B.O.; Narváez-Zapata, J.; Reyes-Estebanez, M.; Quintana, P.; De la Rosa-García, S.; Bullen, H.; Gómez-Cornelio, S.; Chan-Bacab, M.J. Bioweathering potential of cultivable fungi associated with semiarid surface microhabitats of Mayan buildings. Frontiers in Microbiology 2016, 7, 201, doi: 10.3389/fmicb.2016.00201.

45. Caneva, G.; Maggi, O.; Nugari, M.P; Pietrini, A.M.; Piervittori, V.; Ricci, S.; Roccardi, A. The biological aerosol as a factor of biodeterioration. In: Cultural heritage and aerobiology. Methods and Measurement Techniques for Biodeterioration Monitoring; Mandrioli, P., Caneva, G., Sabbioni, C., Eds.; Springer Science+Business Media: Dordrecht, Netherlands, 2003, pp. 3-29, ISBN 978-94-017-0185-3.

46. Savković, Ž.; Stupar, M.; Unković, N.; Knežević, A.; Vukojević, J.; Ljaljević Grbić, M. Fungal Deterioration of Cultural Heritage Objects. In: Biodegradation. IntechOpen, 2021. Available online: https://cdn.intechopen.com/pdfs/77254.pdf (accessed on 12 July 2021).

47. Garg, K.L.; Jain, K.K.; Mishra, A.K. Role of fungi in the deterioration of wall paintings. Science of the Total Environment 1995, 167, 255-271, Available online: http://www.nrlc.gov.in/images/pdf/34.pdf (accessed on 12 July 2021).

48. Dornieden, Th.; Gorbushina, A.A.; Krumbein, W.E. Patina - physical and chemical interactions of sub-aerial biofilms with objects of Art. In: Of microbes and art: The role of microbial communities in the degradation and protection of cultural heritage; Ciferri, O., Tiano, P., Mastromei, G., Eds.; Kluwer Academic Publishers: Dordrecht, Netherlands, 2000, pp. 105-119.

49. Warscheid, T.; Braams, J. Biodeterioration of stone: a review. International Biodeterioration E Biodegradation 2000, 46, 343-368, doi: 10.1016/S0964-8305(00)00109-8.

50. Trovão, J.; Gil, F.; Catarino, L.; Soares, F.; Tiago, I.; Portugal, A. Analysis of fungal deterioration phenomena in the first Portuguese King tomb using a multi-analytical approach. International Biodeterioration E Biodegradation 2020, 149: 104933, doi: 10.1016/j.ibiod.2020.104933.

51. Horner, W.E.; Helbling, A.; Salvaggio, J.E.; Lehrer, S.B. Fungal allergens. Clinical Microbiology Reviews 1995, 8:2, 161-179, doi: $\underline{10.1128 / C M R .8 .2 .161}$

52. Kasprzyk, I. Aeromycology - Main research fields of interest during the last 25 years. Annals of Agricultural and Environmental Medicine 2008, 15:1, 1-7.

53. Simeray, J.; Chaumont, J.P.; Léger, D. Seasonal variations in the airborne fungal spore population of the East of France (Franche-Comte). Comparison between urban and rural environment during two years. Aerobiologia 1993, 9, $201-206$.

54. American Conference of Governmental Industrial Hygienists. Threshold limit values for chemical substances and physical agents and biological exposure indices. ACGIH. 1995.

55. Rao, C.Y.; Burge, H.A.; Chang, J.C. Review of quantitative standards and guidelines for fungi in indoor air. Journal of the Air $\mathcal{E}$ Waste Management Association 1996, 46, 899-908, doi: 10.1080/10473289.1996.10467526.

56. Kolwzan, B.; Adamiak, W.; Grabas, K; Pawe1czyk, A. Introduction to environmental microbiology; Oficyna Wydawnicza Politechniki Wroclawskiej: Wroclaw, Poland, 2006; Available http://www.oficyna.pwr.edu.pl/wp-content/media/Ko\%C5\%82wzan-B.-Adamiak-W.-Grabas-K.-Pawe\%C5\%82czyk-A.-Introd uction-to-environmental-microbiology.pdf (accessed on 12 July 2021).

57. Savković, Ž.; Stupar, M.; Unković, N.; Ivanović, Ž.; Blagojević, J.; Popović, S.; Vukojević, J.; Ljaljević Grbić, M.; Diversity and seasonal dynamics of culturable airborne fungi in a cultural heritage conservation facility. International Biodeterioration $\mathcal{E}$ Biodegradation 2021, 157: 105163, Available online: https://doi.org/10.1016/j.ibiod.2020.105163 (accessed on 12 July 2021). 